\title{
CLINICAL AND ANAMNESTIC FEATURES OF THE COURSE OF ACUTE BRONCHITIS IN CHILDREN
}

\author{
Strelkova M., Senatorova G.
}

\section{Kharkiv National Medical University, Ukraine}

\begin{abstract}
The purpose of the study was to detect clinical and anamnestic features of the course of acute obstructive bronchitis in children with a background of undifferentiated connective tissue dysplasia. Dynamic examination of 42 children with acute obstructive bronchitis was performed. The registration card for all children was developed and filled, it consisted of several sections: general information, family history, allergic history, life and past medical history, phenotypic assessment of undifferentiated connective tissue dysplasia. The results indicate that compromised allergic and genealogical history, as well as burdened obstetric history of the mother (threatened preterm delivery and gestosis) is significant risk factors.

Assessment of clinical manifestations of acute obstructive bronchitis in children showed that the severity of the disease, which is determined by the degree of severity and duration of symptoms, was associated with the number of signs of UCTD.

Keywords: acute obstructive bronchitis, children, undifferentiated connective tissue dysplasia, wheezing, phenotypic assessment.
\end{abstract}

Introduction. Acute obstructive bronchitis (AOB) in young children persists in contemporary pediatrics, despite the scientific and practical achievements in the field of etiopathogenesis of the disease and introduction of current therapies into the medical practice $[1,2,3,18]$.

The prevalence of $\mathrm{AOB}$ according to the authors listed ranges from 15 to $50 \%$ [1, 2] and incidents of acute obstructive bronchitis in infants reaches $90 \%[5,6]$. AOB is mostly manifested in infaants in their first year of life and depends on morphofunctional features of the respiratory system at this age: narrowness of the respiratory tract, weak cartilages of the bronchial tree, and insufficient development of smooth muscle of the bronchial tubes which is one of the proofs of the theory of relative immaturity of all organs and systems in early childhood [7, 4, 17].

A special place in the formation of increased bronchoreactivity in infants and development of AOB is occupied by neuroreflectory mechanisms which are based on dysfunction of autonomic nervous system stipulated by bronchospasms,

Corresponding Author:

Strelkova Maryna, PhD-student of Department

of Pediatrics 1 and Neonatology

of Kharkiv National Medical Univeristy, Ukraine.

E-mail:m.strelkova.doc@gmail.com vasodilation, hyperproduction of high secretion and triggering the development of AOB [3, 5, 19].

Results of many studies have been published recently. The authors consider bronchial dysfunction as a manifestation of autonomic dysfunction due to the disorder of the cartilage and connective tissue of the trachea and the bronchial tubes secondary to undifferentiated connective tissue dysplasia (UCTD) resulting in tracheobronchial dyskinesia [6, 9, 10, 12], and disorder of both drainage and ventilation functions of bronchial tubes.

Changes in connective tissue related to the disorder of synthesis and function of derivatives of collagen and elastic proteins are called connective tissue dysplasia. The definition was offered by P. Âeighton (1983) [5]. It is a polygenic multifactorial state, manifested by external and internal phenotypic features and clinically significant dysplastic-dependent disorders of organs and systems with progressive presentation.

The pathological state of connective tissue leads to the disorder of its functions, which is important for the development of many diseases because of the disorder of the functions of other tissues, for instance, dystrophy (protein, fat) and immune reactivity decreasing with the further development of allergic autoimmune reactions.

A change in almost all of the functions of the connective tissue secondary to a decrease in 
adaptive capacity of the organism leads to the development of different clinical variants in manifestation of connective tissue insufficiency.

Vegetative dysfunction is an important component of UCTD in children with obstructive bronchitis (OB). It is manifested by eructation, colics, low weight gain, and respiratory disorders with respiratory failure in young children secondary to UCTD. In these cases arrhythmic breathing is associated with gastroesophageal reflux (manifestation of UCTD). When brought together, these factors are important in the formation of relapses of acute obstructive bronchitis: disorder evacuation of the bronchial secretion, hyperkinesia, and the consequences of gastric reflux.

Mucostasis and disturbance of the drainage function of the bronchial tubes in OB provide favorable conditions for permanent colonization of the bronchial tree by microorganisms.

Relapses of acute obstructive bronchitis in young children, their anatomical and physiological features, and growing allergization of the modern society create a pathophysiological complex that promotes further development of bronchial asthma in children.

\section{Purposes, subjects and methods:}

2.1. Purpose - is to detect clinical and anamnestic features of the course of acute obstructive bronchitis in children secondary to undifferentiated connective tissue dysplasia.

2.2. Subjects \& Methods. The study was a one-stage cohort, and the sampling method was continuous (during hospitalization). The key population was children admitted for examination and treatment at the Department of Pulmonology. Inclusion criteria were as follows: age 5 years and younger, obstructive bronchitis in history (one or more), and parental consent to participate in the study. Exclusion criteria were diagnosed bronchial asthma, chronic somatic diseases at the stage of exacerbation, malformations of internal organs, congenital and hereditary diseases of the bronchopulmonary system and gastroesophageal reflux.

As a part of a study only one program of clinical and laboratory examination has been used to evaluate the criteria for the selected parameters.

The registration card for all children was developed and filled, it consisted of several sections: general information, family history, allergic history, life and past medical history, phenotypic assessment of UCTD (according to T.I. Kadurina, L.N. Abakumova, 2008), and the results of examination at the specialized department $[1,7,15,20]$.

Statistical analysis of data was carried out using statistical software STATISTICA 10.0. Non-parametric Mann-Whitney U-test was used to assess the differences between the two groups in quantitative terms. The estimation of intergroup differences by qualitative features was carried out using the criterion $\chi 2$ and Fisher's exact criterion.

Conflict of interests. There is no conflict of interests.

3. Results and discussion. According to the inclusion/exclusion criteria, 42 children with OB were included in the study and the average age of children was $3.2 \pm 1.3$ years. The children were divided into the following groups: main Group $1(\mathrm{n}=30)$ comprised children with acute obstructive bronchitis and phenotypic manifestations of undifferentiated connective tissue dysplasia, and control Group $2(\mathrm{n}=12)$ included children with acute obstructive bronchitis without phenotypic manifestations of UCTD. The observation was conducted in the acute phase of the disease throughout the whole course of hospital treatment. The diagnosis of bronchitis was based on generally accepted clinical criteria, for the comparative description of the diseases, depending on the presence of UCTD the severity of clinical manifestations was evaluated in points. Diagnosis of UCTD implied assessment of stigmatization levels (a conditional indicator including the total number of UCTD points with the extraction of low (up to 12 points), middle (13-24 points) and high (more than 24 points) levels (using the table "Value of indices in the assessment of the degree of connective tissue dysplasia severity" by T.I. Kadurina, L.N. Abakumova, 2008). Group 1 children comprised 11 girls (36.7\%) and 19 boys (63.3 \%), and Group 2 included 3 boys (25\%) and 9 girls (75 \%) (Fig. 1).

The findings showed $(\mathrm{p}<0.05)$ that boys predominated among the examined children with AOB and UCTD.

According to the questionnaire, the compromised allergic history was significantly more frequent $(\mathrm{p}<0.05)$ in main group children (22 children from Group 1 (73.4\%), and 4 children from Group 2 (33.3\%).

The genealogical history of probands included information about the health of relatives in three generations, with a significantly higher frequency $(p<0.05)$ of burdened family history of chronic bronchopulmonary diseases (bronchial asthma, chronic obstructive pulmonary diseases) in three 


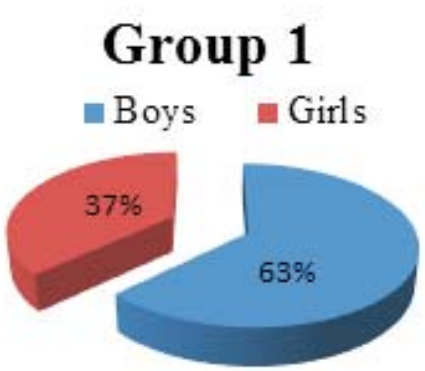

Fig. 1. Distribution of children in the groups under investigation by gender

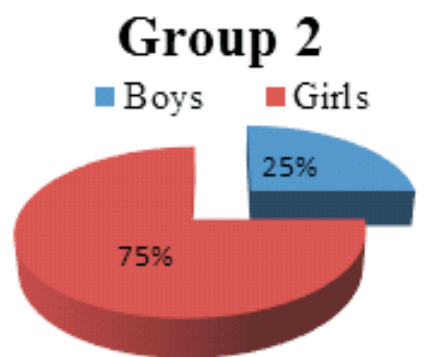

External phenotypic manifestations of UCTD in patients of the main group were more common ( $p<0.05$ ) than in children of the other group, (53.4\%)) and only 2 children from Group 2 (16.7\%) (Fig. 2).

generations of Group 1 children (16 children

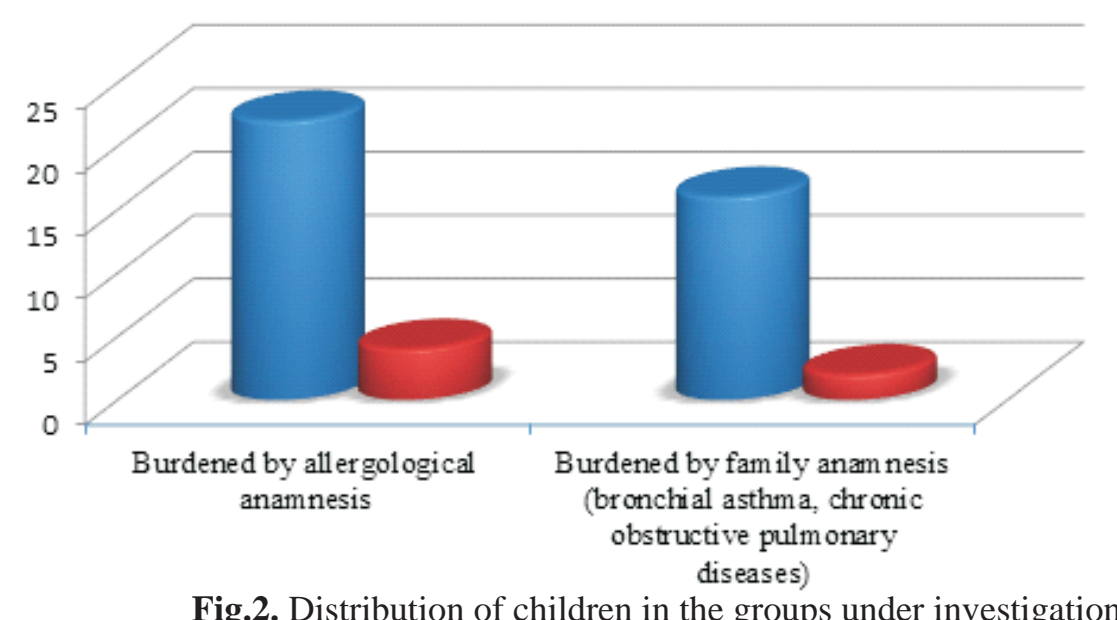

Fig.2. Distribution of children in the groups under investigation by burdened allergic and genealogical history
Among the mothers of the main group 19 mothers (63.3\%) had a risk of preterm delivery, which was significantly higher $(\mathrm{p}<0.05)$ than in mothers of the other group (3 mothers, $25 \%$ ).

Also, the mothers of the control group had more manifestations of gestosis (70 \%), among the other group only 4 women (30\%) had manifestations of gestosis (Fig. 3). namely asthenic build, thin skin, soft and brittle nails, diastase of the abdominal muscles, fine and brittle hair and blue sclera (Table).

Examination of Group 1 children showed moderate degree of UCTD in 25 children (83.3\%), expressed as CTD in 5 (16.7\%) patients.

Assessment of clinical manifestations of AOB in children showed that the severity of the disease,

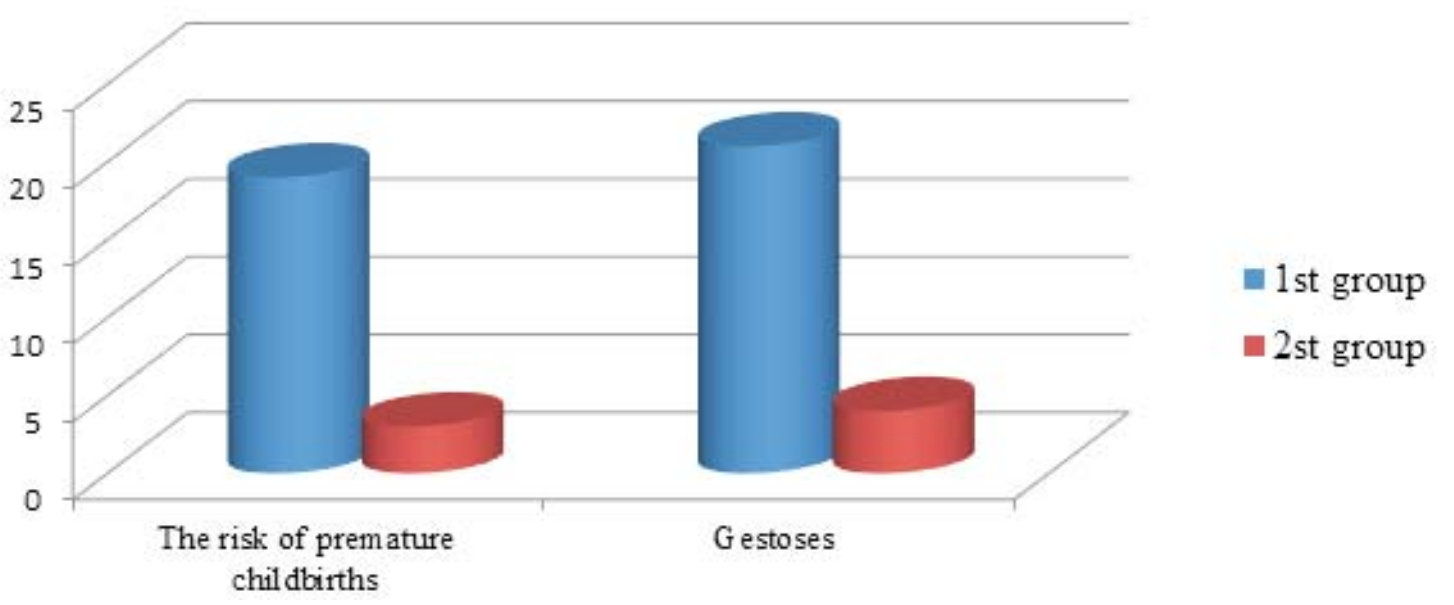

Fig. 3. Distribution of mothers of children in the groups under investigation according to burdened obstetric history (the risk of preterm delivery and gestosis) 
Incidence of phenotypic signs of UCTD in patients of the groups under investigation

\begin{tabular}{|c|c|c|c|c|}
\hline \multirow[t]{2}{*}{ Phenotypic signs of UCTD } & \multicolumn{2}{|c|}{$\begin{array}{c}\text { Group } 1 \\
(n=30)\end{array}$} & \multicolumn{2}{|c|}{$\begin{array}{c}\text { Group } 2 \\
(n=12)\end{array}$} \\
\hline & $\%$ & absolute & $\%$ & absolute \\
\hline Asthenic body composition & $53.3 *$ & 16 & 16.7 & 2 \\
\hline Dolichostomenoeia & 16.7 & 5 & 8.35 & 1 \\
\hline Arachnodactyly & 3.3 & 1 & - & - \\
\hline Hypermobility of the joints: moderate degree & $50.0 *$ & 15 & 8.35 & 1 \\
\hline Velvet, soft skin & 26.6 & 8 & 33.4 & 4 \\
\hline Thin skin (moderate venous mesh) & $60.0 *$ & 18 & 16.7 & 2 \\
\hline $\begin{array}{c}\text { Hyperelasticity of the skin: } \\
\cdot \text { low; } \\
\cdot \text { moderate. }\end{array}$ & $\begin{array}{c}40.1 \\
9.9\end{array}$ & $\begin{array}{l}9 \\
3 \\
\end{array}$ & $\begin{array}{c}33.4 \\
-\end{array}$ & $\begin{array}{l}4 \\
- \\
\end{array}$ \\
\hline Nails (soft / brittle / flaky) & $53.3 *$ & 16 & 16.7 & 2 \\
\hline Ears (soft / folded in a tube) ${ }^{*}$ & $53.3 *$ & 16 & 16.7 & 2 \\
\hline Blue sclera & $53.3 *$ & 16 & 8.35 & 1 \\
\hline Petechia / ecchymosis / nosebleeds & 20.0 & 6 & 16.7 & 2 \\
\hline Myatonic syndrome / diastasis of the direct abdominal muscles & 23.3 & 7 & 8.35 & 1 \\
\hline Hernias/prolapse of organs / postoperative hernias & 9.9 & 3 & 16.7 & 2 \\
\hline Hair (thin / brittle / areas of alopecia) & $63.3 *$ & 19 & 25.0 & 3 \\
\hline $1^{\text {st }}$ degree scoliosis & 13.6 & 3 & 16.7 & 2 \\
\hline Flat-foot transverse / longitudinal & 13.6 & 3 & 8.35 & 1 \\
\hline Pes valgus. Valgus deformation of the & 9.1 & 2 & 8.35 & 1 \\
\hline
\end{tabular}

Note. ${ }^{*} \mathrm{p}<0.05$ when compared to Group 2 patients.

determined by the degree of severity and duration of symptoms, was associated with the number of UCTD signs. Thus, febrile fever in children of the main group was registered 3.5 times more often than in the other group (in 86.7 and $25.0 \%$ of cases, respectively); $\mathrm{p}<0.05$, while the terms of normalization of body temperature in $40.0 \%$ of patients with UCTD were more than 5 days. Characteristics of cough in children of both groups did not have significant differences except in the long term perseverance of this symptom in patients with UCTD. Auscultatory changes were characterized by dry whistling and scattered damp melliferous wheezing secondary to prolonged exhalation. In children of the comparison group, the clinical symptoms of GBS lasted for $3.4 \pm$
1.2 days, while in Group 1 children clinical symptoms (dry whistling wheezing and prolonged exhalation) persisted for $5.2 \pm 1.8$ days.

Conclusions. Connective tissue dysplasia has a modifying effect on the course of acute bronchitis, resulting in greater severity and prolongation of the leading symptoms and syndromes, and the significant risk factors is the presence of a compromised allergic and genealogical history, as well as burdened obstetric history of the mother (threatened preterm delivery and gestosis). This emphasizes the need for the improvement of the program of examination of children with acute obstructive bronchitis for the prognosis of the course and optimization of treatment and rehabilitation measures.

\section{References:}

1. Ducharme FM, Tse SM, Chauhan B. (2014). Diagnosis, management, and prognosis of preschool wheeze. Lancet. 2014 May 3;383(9928):1593-604. doi: 10.1016/S0140-6736(14)60615-2.

2. Martinez FD, Wright AL, Taussig LM, Holberg CJ, Halonen M, Morgan WJ. (1995). Asthma and wheezing in the first six years of life. N. Engl. J. Med, 332: 133-138. doi: 10.1056/NEJM199501193320301.

3. Chuchalin A.G., Il'kovich M.M. Pulmonology handbook. (2014) Spravochnik po pul'monologii Handbook of Pulmonology.] Moscow: GEOTAR-Media. 2014; pp.928.

4. Lasso-Pirot A., Delgado-Villalta S., Spanier AJ. (2015). Early childhood wheezers: identifying asthma in later life. J Asthma Allergy, 8, 63-73. doi: 10.2147/JAA.S70066

5. Davidenko E.V. (2014) Prognozirovanie razvitija bronhial'noj astmy u detej s ostrym obstruktivnym bronhitom v rannem vozraste Prediction of the development of bronchial asthma in children who had acute obstructive bronchitis at an early age]. Nauchnye vedomosti. Seriya Meditsina. Farmatsiya. ${ }^{1} 4$ (175), 89-91.

6. Daykhin Ye.I., Kozlova N.I., Sivanova L.A. (1983) Nekotoryy eaktualnye problemy biokhimicheskoy diagnostiki patologii soyedinitelnoy tkani Some actual problems of biochemical diagnostics of connective tissue pathology.]. Pediatriya, ${ }^{1}$ 4, ðð. 68-70. . 
7. Fedorov I.A., Rybakova O.G., Stepanov O.G. (2017) Diagnostika bronkhial'noi astmy u detei, perenesshikh epizody ostrogo obstruktivnogo bronkhita v doshkol'nom vozraste Diagnosis of bronchial asthma in children who had acute obstructive bronchitis at preschool age.]. Human. Sport. Medicine, vol. 17, no. 1, pp. 28-35.

8. Luo G., Nkoy F.L., Stone B.L., Schmick D., Johnson M.D. (2015) A systematic review of predicitve models for asthma development in children. BMC. Med. Inform. Decis. Mak.,15, p.99. doi: 10.1186/ s12911-015-0224-9.

9. Gaparkhoeva Z.M., Bashkina O.A., Seliverstova. E.N. (2016) Sravnitel'naya kharakteristika triggernykh mekhanizmov formirovaniya bronkhoobstruktivnogo sindroma u detei s bronkhial'noi astmoi i retsidiviruyushchim obstruktivnym bronkhitom Comparative characteristics of the trigger mechanisms of the formation of bronchial obstruction syndrome in children with bronchial asthma and recurrent obstructive bronchitis.]. Kazanskii meditsinskii zhurnal, ${ }^{1}$ 1, pp. 66-69.

10.Halper J., Kjaer M. (2014) Basic components of connective tissues and extracellular matrix: elastin, fibrillin, fibulins,fibrinogen, fibronectin, laminin, tenascins and thrombospondins. Adv. Exp. Med. Biol., 802, pp. 31-47.

11.Katilov A.V., Laiko L.I., Dmitriev D.V., Zaikov S.V. (2017) Ostryi bronkhit u detei: printsipy diagnostiki i terapii Acute bronchitis in children: principles of diagnosis and treatment]. Medical Nature, 1 (21), pp.16-20.

12.Kavlak E., Buker N., Altug F., Kitis A. (2014) Investigation of the effects of connective tissue mobilization on quality of life and emotional status in healthy subjects. Afr. J. Tradit., Complement. Alternative Med., 11(3), p. 160.

13.Lapshin V.F. Retsidiviruyushchii bronkhit u detei: diskussionnye voprosy diagnostiki i lecheniya (2017) Recurrent bronchitis in children: controversial issues of diagnosis and treatment]. Ped ${ }^{3} \operatorname{atr}^{3} \mathrm{ya}^{1} 2$ (41), p. 10-11.

14.Lee P, Khoo KL. (2012) A review of current bronchoscopic interventions for obstructive airway diseases. Ther Adv Respir Dis., 6, pp.297-307.

15. Mizernitskii, Yu.L. (2014) Differentsial'naya diagnostika i differentsirovannaya terapiya ostroi bronkhial'noi obstruktsii pri ORVI u detei rannego vozrasta Differential diagnosis and differential therapy of acute bronchial placement in acute respiratory viral infections in young children]. Prakt. Meditsina, 19 (85), pp. 82-88.

16. Nesterenko Z.V. (2017) Retsidiviruyushchii bronkhit kak klinicheskii variant funktsional'nykh izmenenii respiratornoi sistemy u detei Recurrent bronchitis as a clinical variant of the functional changes in the respiratory system in children]. Pediatr., T.8., ${ }^{2}$ 5, pp. 44-48. doi: 10.17816/PED8544-48

17. Nesterenko Z.V., Gritsai A.A. (2014) Features of respiratory diseases in children with connective tissue disorders [Osobennosti boleznei organov dykhaniya u detei s displaziei soedinitel'noi tkani]. Har'kov: Schedra sidiba pljus.].

18.Pochivalov A.V., Ivannikova A.S., Bugrimov D.Yu., Tsvetikova L.N. (2013) Effect of connective tissue dysplasia on for respiratory diseases in children. [Vlijanie zabolevanij soedinitel'noj tkani u detej]. Nauchnye vedomosti belgorodskogo gosudarstvennogo universiteta. Seriya: Meditsina. Farmatsiya., 124 (25), ðð. 45-49.].

19.R. Mattiello, J. Mallol, G. B. Fischer. (2012) Pulmonary function in children and adolescents with postinfectious bronchiolitis obliteransp J. Bras. Pneumol. 2012. Vol. 4, 453-459.

20.Zhelenina L.A., Galustyan A.N., Platonova N.B., Kuropatenko M.V. (2016) Contribution of prenatal factors and in formation of asthma phenotypes in children [Vklad perinatal'nykh faktorov riska $\mathrm{V}$ formirovanie fenotipov bronkhial'noi astmy v detskom vozraste]. Pediatr T. 7, 1 2, pð. 47-56.]. doi: 10.17816/PED7247-56

Received: 24-Jun. - 2018

Accepted: 12-Sep. - 2018 